\title{
ADAPTATION OF CIVIL SERVANTS AS A PRIORITY OF THE HR-MANAGEMENT OF THE CIVIL SERVICE OF UKRAINE
}

\section{Selivanov S. V., Kashlakova A. I.}

\section{INTRODUCTION}

Entry into the civil service from the point of view of a newly appointed civil servant entails the following whole growth, deserving of respect of the collective and the possibility of preserving the "ideology" inherent in young professionals.

According to the Law of Ukraine "On Civil Service" of 10.12.2015 No. 889-VIII one of the key directions of development of the civil service in Ukraine is to ensure continuous professional development of civil servants, an integral component of the mechanism of implementation of which is adaptation ${ }^{1}$.

The continuity of knowledge, skills and experience of civil servants plays an important role in the efficiency of the functioning of public bodies, ensuring the integrity of the organization, the quality of its functions and compliance with the accepted rules of behavior and mode of work. Given the increasing burden on public authorities, the importance of quality and rapid adaptation of newly recruited staff to working and collective conditions is increasing.

Adaptation of a civil servant in the field of professional activity is an important component of the public administration system. The imperfection of the system of adaptation of the civil servant at the initial stage of the replacement of the public position can lead to the fact that the civil servant will feel a sense of alienation and negatively treat both the state body of which he is an employee and the sphere of professional activity as a whole.

This issue is actualized in connection with the constant updating of the composition of civil servants (annual update is about 10 thousand

${ }^{1}$ Про державну службу : Закон України від 10 грудня 2015 року № 889-VIII. Відомості Верховної Ради України : офіційне видання від 22.01.2016, 2016 р., № 4, стор. 60 , стаття 43 . 
people). For the first time entering the civil service, staff faces a number of problems: uncertainty in the correctness of their actions, lack of knowledge of the features of activities in a specific structure of the apparatus, gaps in knowledge of the legislation.

These circumstances determine the objective need to develop and implement reliable HR-tools for adapting newly recruited employees to the civil service, as a leading strategic factor in modernizing public administration, which determines its success at the stage of "implementation of European standards of living in Ukraine".

\section{The essence of professional adaptation}

Recruitment adaptation programs are an auxiliary tool for person-towork and workforce adjustment, and vice versa. Adaptation involves an active position of the organization and personality, awareness of its social status and related role behavior, as a form of realization of individual capabilities of the individual in the process of solving common tasks.

Practitioners have identified that the adaptation of public service personnel has two aspects: intra-psychological and external organizational. Thus, the intra-psychological aspect of the civil servant's adaptation depends on his/her psychological nature, during which he/she becomes accustomed to previous work and getting used to the new one, acquaintance with and accepting/rejecting the values of the organization, formal and informal organizational rules. External organizational aspect of civil servant adaptation is a set of measures from the service staff, management, colleagues, aimed at facilitating the introduction of a new employee in the organization, such as assistance in mastering skills, mentoring, familiarity with formal and informal rules. Adaptation of staff is understood as the adaptation of an employee to working conditions in a state body ${ }^{2}$.

The level distinguishes between primary (for persons with no work experience) and secondary adaptation; by orientation - professional, psychophysiological and socio-psychological.

Professional adaptation is the active development of the profession, its intricacies, specifics, necessary skills, techniques, decision-making methods to start in standard situations. It starts with the fact that after finding out the experience, knowledge and character of the newcomer,

2 Перерва А. Адаптація як пристосування працівника до умов праці в державному органі. Журнал «Держслужбовеиь», липень 2018, № 7. 
they determine the most appropriate form of training for him, for example, direct him to training courses or attach a mentor to him. The main elements of professional adaptation are: mastering the system of professional knowledge and skills; fulfillment of requirements of service and executive discipline; independence in the performance of official duties; aspiration to improve the chosen profession (position).

Psychophysiological adaptation consists in the adaptation of the newly appointed civil servant to the conditions of work, work and rest and does not cause any special complications, proceeds rather quickly and depends to a great extent on the health of the person, his natural reactions. These conditions include physical and mental stress, the level of monotonicity of work, hygienic conditions, rhythm of work, compliance of the workplace with ergonomic requirements, etc. Most accidents are believed to occur in the first days of work.

Socio-psychological adaptation is an adaptation to a collective and its norms, to management and colleagues, to economic realities. It can be associated with considerable difficulties, such as the futile expectation of rapid success due to the underestimation of obstacles, the importance of human experience and the reassessment of the value of theoretical knowledge and instruction. The functions of social and psychological adaptation of an employee in a team include: his socialization (development of social experience and value system of the team); acquiring new character traits (purposefulness, activity in support of the team goals); the formation of psychological comfort and security (selfconfidence and tomorrow); formation of interest in work (see prospect, possibility of realization of the potential).

Most people in the first days of work are most afraid of not coping with a new position, showing lack of experience and knowledge, showing incompetence, not finding a common language with their manager and colleagues, not being accepted by the team, and consequently losing their jobs or job prospects. Therefore, the first task for a beginner should be not too simple and not too difficult, so that he could handle it and at the same time feel satisfied. The HR specialist should facilitate successful adaptation, as it usually coincides with the probationary period of the employee.

All types of labor adaptation are interrelated and inseparable sides of a single process, though professional adaptation is crucial. 
Implementation and improvement of the civil servant adaptation system can lead to the following positive results ${ }^{3}$ :

-forcing the process of entry into the position of a recruited employee and improving the efficiency of activities in a short time,

-minimization of service losses and errors in the process of adaptation and assimilation of official duties,

- reduction of staff turnover,

- the development of a positive attitude towards professional activity and the relevant public authority.

Thus, the adaptation of civil servants provides for the process of including a civil servant as a person in the organizational environment of public authorities.

Adaptation of civil servants in the field of professional activity (professional, psychophysiological, socio-psychological and organizational) is an important component of the public administration system. The imperfection of the system of adaptation of the stateadministrative personnel at the initial stage of the replacement of the state position can lead to the fact that they will feel alienated and adversely affect both the state body in which they work and the sphere of professional activity in general. In the process of adaptation, there is an impact, as an individual on the organization, and the organization on the individual. It follows that adaptation is a process of mutual adaptation of a civil servant and a public authority in order to realize the acquired professionalism and develop the competencies of the employee ${ }^{4}$.

Implementation and improvement of the system of adaptation of the civil service personnel can lead to the following positive results: forcing the process of admission of a recruited employee to the position and increasing the efficiency of activities in a short time; minimizing losses and errors in the process of adaptation and assimilation of duties; reduction of staff turnover; the development of a positive attitude towards professional activity and the relevant public authority as a whole.

3 Маслова В.М Управление персоналом : учебник и практикум для академического бакалаврита. 2-е изд., перераб. и доп. Москва : Издательство Юрайт, 2015. 492 с. Серия : Бакалавр. Академический курс.

${ }^{4}$ Селіванов С.В., Обушна Н.І., Хаджирадєва С.К. Розвиток кадрового потенціалу державної служби в Україні в умовах реформ : проблеми теорії та практики : монографія. Київ : Вид-во «Каравела», 2019. 292 с. 
In the process of adaptation, which integrates internal psychological processes, a civil service employee is "dropped out" of the usual mode of activity and must be mobilized at a new place of professional activity through various methods of adaptation, namely:

- coaching (explaining and demonstrating the basics, rules and practices directly in the workplace);

- courses (eg refresher courses), trainings, seminars;

- apprenticeships and mentoring (tutorship, tutoring, coaching);

- shadowing or jobshadowing, in which a new employee becomes the "shadow" of a more experienced employee, accompanies him during the working day, discusses production situations with him;

-buddying (from buddyng - friendly relations) involves the adaptation of a new employee through mentoring, but in the form of friendly relations;

- business games and more during which the abilities of the newly appointed employee are revealed, the role of personal potential in various types of activity is revealed, namely efficiency and special abilities, activity in the form of value orientations, motives.

\section{The most important components of the process of professional adaptation of civil servants}

\subsection{Professional and formal training tools for civil servants in the adaptation process}

In general, in support of N. Rashitova's point of view, we consider that the components of the adaptation of personnel in the civil service are $^{5}$ :

- assignment to individual employees of the personnel management service of the state body the functions of adaptation management, providing advisory assistance to line managers on adaptation issues;

-implementation of the mentoring institute's practice at the legal and regulatory level;

- creation of a special package of documents, which will include general information about the activity of the organization, its structure,

5 Рашитова Н.К. Адаптація до професійної діяльності на державній службі: соціально-психологічний аспект : автореф. дис. ... к.е.н. : спец. 25.00.03 «Державна служба». Дніпропетровський регіональний інститут державного управління. Дніпропетровськ, 2007. С. 15. 
basic general requirements and responsibilities of employees, programs of activity of the authority, etc.

- on-the-job training (within the employee's job functions);

- off-the-job training.

In accordance with each of the identified forms and methods, a specific set of tools is formed by which these methods and forms are implemented. For example, one of the tools in the field of vocational formal education is the Professional Development Programs (PPPCs), which are compulsory for every newly appointed civil servant during the first year of employment and at least once every three years. Although PPPCs are designed to develop knowledge, skills, and attitudes in the civil service as an institution capable of continuously developing open and effective, steadily governed governance, responding to the needs of society, and being aware of the country's economic and political position, they are unlikely to meet all education and training.

According to $\mathrm{M}$. Memon, the tools of non-formal learning include: mentoring, self and others evaluation, experimental research, selfreflection, peer learning, team consultations, team work, learning from team members, observation of positive practice, participation in conferences, seminars, workshops, feedback, participation in reporting, organizational development, online learning program, research activities, search for grants, reflection ${ }^{6}$. However, tutorship and mentoring, coaching and tutoring are the most common tools of non-formal vocational training in the world today.

All the mentioned concepts ("tutorship", "mentoring", "tutoring" and "coaching") are close in meaning, as they testify to certain relationships that arise between an experienced person and a person in need of appropriate development:

- tutorship is a learning partnership between two or more individuals who wish to share experiences or develop a common interest ${ }^{7}$;

-it is considered as a way to support the employee, and the relationship between the mentor and his tutor is most accurately described by the formula "teacher - student", that is, the tutor is

${ }^{6}$ Нижник Н.Р. Проблеми сьогодення державного управління в Україні. Університетські наукові записки. 2007. № 3 (23). С. 14-19.

7 Tillman L.C. Mentoring new teachers: Implications for leadership practice in an urban school. Educational Administration Quarterly. 2005. No 41(4). Pp. 609-629. 
considered here as a person subordinate to the mentor ${ }^{8}$. At the same time, in the Western tradition, the terms such as "supervisor" and "supervisor" are also conveyed to the understanding of the mentor: supervisor supervising person, supervisor';

- mentoring (from Greek men - the one who thinks tor - a suffix meaning male gender) - the relationship between an individual seeking guidance and a person experienced in a particular field. The mentor shares his experience and knowledge, acts as an authoritative advisor. The goal is determined by the guardian (or mentor if the ward asks for help). Achieving this goal can lead to a new goal that will promote career progression ${ }^{10}$. That is, in mentoring, unlike mentoring, provision is made for "the acquisition of wisdom", and the initiative belongs to the ward itself;

-tutoring is an educational technology based on the theory of personality formation. By Random House KernermanWebster's College Dictionary ${ }^{11}$;

- a tutor is a person who is instructed to instruct others, especially personally; University staff member responsible for teaching and supervising students (especially in Oxford and Cambridge). According to N. Akinina, the tutoring effect is that students not only "ask themselves conscious questions about the meaning of their own actions, but, in the end, find internal incentives for learning. They discover the causes and their own priorities for studying a particular subject. In this way, the tutor helps the student to become a subject of their own educational activities";

- coaching - "a process that enables learning and development to occur and thus improves task performance" (E. Parsloe, author of "Manager as Coach and Mentor") ${ }^{12}$. It is used to disclose existing skills,

8 Coaching and mentoring - the difference. Brefi Group. URL: http://www.brefigroup.co.uk/coaching/coaching_and_mentoring.html.

9 Поліщук І.В. Механізми забезпечення розвитку професійного потенціалу державних службовців в Україні : дис. ... канд. наук з державного управління. Київ, 2018.315 с. С. $177-178$.

${ }^{10}$ What's the difference between coaching, mentoring, counselling and training? Culture Shock Coaching. 13.10.2010. URL: ttps://cultureshockcoaching. wordpress.com/2010/10/13/hello-world/.

11 Random House Kernerman Webster's College Dictionary, 2010. K Dictionaries Ltd. by Random House, Inc. URL: http://www.kdictionaries-online.com.

${ }^{12}$ Parsloe E. The manager as coach and mentor. London : Institute of personnel and development, 1999. $89 \mathrm{p}$. 
typically in three ways: public servant coaching, team coaching, and executive coaching.

Based on the analysis of the literature on HR management, it can be noted that the essence of tutorship is that an experienced specialist trains a new employee because he knows himself. Tutorship is aimed at acquiring the new employee with the knowledge, skills and skills needed in his future work. With the help of a personal example, the mentor transfers his experience to the mentee. It can be said that this is a form of individual learning directly in the workplace. Unlike coaching, coaching is focused not so much on direct learning, but on how to maximize the full potential of a new employee and get him full impact in the work. Coaching is based on the fact that each person has much more ability than he usually has. And the coach in his work relies not so much on the employee's current performance, but on his potential, which he seeks to unlock for the benefit of the company. A coach or manager with coaching skills does not give as much guidance and instructs as he or she asks questions. Questions that put the coach on a specific scheme (socalled "effective questions") allow the novice to take a fresh look at their work and their capabilities. At the same time, coaching shows the manager the real professional level of a new employee at the moment and allows him to plan his work on his development. A newcomer can work with a full-time coach or direct supervisor with coaching skills. Today, there is no clearly defined mechanism for professional adaptation of specialists in the civil service. And this is to some extent the cause of civil service staff turnover. At the same time, in our opinion, the main types of professional adaptation nowadays in the civil service are, first, the appointment of a probationary period (at the same time, the probationary period is part of the implementation of the personnel selection mechanism); second, the internship of a candidate before being hired (internships may also be part of the training of a future civil servant $)^{13}$.

In turn, a clear distinction between the above concepts is provided in the work of J. Kenworth "Leadership Coaching: What's Better Today? How to Grow and Learn in the Leader You Can Be"(Table 1).

13 Пархоменко-Куцевіл О.І. Теоретико-концептуальні засади удосконалення механізму адаптації кадрів державної служби Державне управління: теорія та практика. 2010. № 1. URL: https://scholar.google.com.ua/citations?user= 2dzHkEsAAAAJ\&hl=ru. 
Table 1

Comparative analysis of non-formal vocational training tools

in the civil service*

\begin{tabular}{|c|c|c|c|c|}
\hline $\begin{array}{l}\text { Crite- } \\
\text { rion }\end{array}$ & Tutorship & Mentoring & Tutoring & Coaching \\
\hline Focus & $\begin{array}{l}\text { Psychological } \\
\text { comfort }\end{array}$ & $\begin{array}{c}\text { Assistance in } \\
\text { determining the } \\
\text { direction of } \\
\text { development and in } \\
\text { evaluating different } \\
\text { opportunities }\end{array}$ & $\begin{array}{l}\text { Receiving } \\
\text { instructions } \\
\text { and } \\
\text { direction }\end{array}$ & $\begin{array}{c}\text { Receiving } \\
\text { structured } \\
\text { support to find } \\
\text { your own way } \\
\text { of solving } \\
\text { questions }\end{array}$ \\
\hline Context & $\begin{array}{l}\text { Adoption } \\
\text { available } \\
\text { constructive } \\
\text { practitioner }\end{array}$ & $\begin{array}{c}\text { Personal } \\
\text { development for the } \\
\text { future careers and } \\
\text { life }\end{array}$ & $\begin{array}{c}\text { Organizatio } \\
\text { n or team }\end{array}$ & $\begin{array}{l}\text { The work of } \\
\text { the individual }\end{array}$ \\
\hline $\begin{array}{l}\text { Numbe } \\
\text { r wards }\end{array}$ & $1-3$ & $1-3$ & $1-8$ & $10-15$ \\
\hline $\begin{array}{l}\text { Value } \\
\text { from: }\end{array}$ & $\begin{array}{c}\text { Experience } \\
\text { and } \\
\text { professionalis } \\
\text { m } \\
\text { mentor } \\
\end{array}$ & $\begin{array}{c}\text { Experience, } \\
\text { knowledge mentor } \\
\text { and him willingness } \\
\text { to share this } \\
\text { knowledge }\end{array}$ & $\begin{array}{l}\text { Teaching } \\
\text { individuals }\end{array}$ & $\begin{array}{l}\text { Coach skills } \\
\text { and } \\
\text { motivations }\end{array}$ \\
\hline Content & $\begin{array}{l}\text { Based on } \\
\text { needs of the } \\
\text { ward }\end{array}$ & $\begin{array}{l}\text { Based on needs of } \\
\text { the ward }\end{array}$ & $\begin{array}{l}\text { Based on } \\
\text { leaders }\end{array}$ & $\begin{array}{l}\text { Based on the } \\
\text { needs of the } \\
\text { worker seats }\end{array}$ \\
\hline Goal & $\begin{array}{l}\text { Personal } \\
\text { comfort }\end{array}$ & $\begin{array}{c}\text { International } \\
\text { development and } \\
\text { growth }\end{array}$ & Collective & $\begin{array}{c}\text { Improvements } \\
\text { productivity } \\
\text { work } \\
\end{array}$ \\
\hline $\begin{array}{l}\text { Progres } \\
\mathrm{S}\end{array}$ & $\begin{array}{l}\text { Depends on } \\
\text { the complexity } \\
\text { of the tasks }\end{array}$ & $\begin{array}{l}\text { It is based on a } \\
\text { predetermined } \\
\text { purpose }\end{array}$ & $\begin{array}{l}\text { It is often } \\
\text { uneven }\end{array}$ & $\begin{array}{l}\text { It depends on } \\
\text { the motivation }\end{array}$ \\
\hline $\begin{array}{l}\text { Level } \\
\text { of } \\
\text { respon- } \\
\text { sibility }\end{array}$ & Average & High level & Low level & $\begin{array}{l}\text { Medium to } \\
\text { high }\end{array}$ \\
\hline Method & $\begin{array}{c}\text { Method } \\
\text { Thinking and } \\
\text { emotions }\end{array}$ & $\begin{array}{c}\text { Direction and } \\
\text { leadership (heart, } \\
\text { will and the mind) }\end{array}$ & $\begin{array}{c}\text { Society } \\
\text { (heart and } \\
\text { mind) }\end{array}$ & $\begin{array}{l}\text { Questions and } \\
\text { Attempts (will } \\
\text { and reason) }\end{array}$ \\
\hline $\begin{array}{l}\text { Inten- } \\
\text { tion }\end{array}$ & $\begin{array}{l}\text { Personal } \\
\text { comfort on } \\
\text { workplace } \\
\end{array}$ & $\begin{array}{c}\text { Reach Disclosure } \\
\text { career potential and } \\
\text { life }\end{array}$ & $\begin{array}{c}\text { Acquire } \\
\text { knowledge }\end{array}$ & $\begin{array}{c}\text { Improve } \\
\text { productivity }\end{array}$ \\
\hline
\end{tabular}

* Source: Generalized by authors based on ${ }^{14}$

14 Поліщук І.В. Механізми забезпечення розвитку професійного потенціалу державних службовців в Україні : дис. ... канд. наук з державного управління. Київ, 2018.315 с. С. $177-178$.

Kenworthy J. Leadership Coaching: What's Better Today? How to Grow and Learn into the Leader You Can Be. Corporate Edge Asia Pte Ltd, 2013. 163 p. 
Nowadays, such educational HR technologies as business, roleplaying, imitation, situational, didactic and other games are gaining popularity. The educational game is a simulation of a certain situation and its subsequent discussion in real format. Such games are effective in terms of skills and practical skills (plan development, organization of meetings, negotiations, etc.), as well as in establishing behavioral skills such as meeting the needs of citizens, focusing on cooperation. Thanks to the game forms of training, the staff acquires a developing effect, which consists in changing stereotypes, developing the flexibility of thinking, professional skills. However, games are less effective when employees need to acquire theoretical knowledge or acquire new specialties. Coaches are actively using the caseady method. The method of situations involves consideration of industrial, managerial and problem situations, complex conflict cases. When discussing practical situations, there is a discussion or group discussion of a production problem, in which the students play an active role and the trainer regulates and controls the learning process. Consideration of practical situations enables students to familiarize themselves with the experience of other organizations (the content of a specific situation), as well as to develop the skills and practical skills of making management decisions ${ }^{15}$.

Also, state forms of training of trainees are being distributed in state bodies. Not only does the training provide professional knowledge but it also has a great potential for development. Educational training contributes to the intensity of learning, the result of which is achieved through the students' own active work. Knowledge is not given in a ready form, but is acquired in the process of independent work of the training participants. Training is learning by means of action. It enables students to put their knowledge into practice by turning it into a skill ${ }^{16}$.

The main purpose of the training is to provide skills that are as close as possible to practical application, which can be applied in practical activities without further training. The training uses problematic situations from the activities of the participants, which are played and analyzed by a group with the participation of specialists. The training

15 Підвищення ефективності використання персоналу та його розвиток : монографія / за науковою редакцією доктора економічних наук А.Г. Бабенка. Дніпропетровськ : УМСФ, 2016. 328 с. ISBN 978-966-328-108-7 С. 85.

16 Підвищення ефективності використання персоналу та його розвиток : монографія / за науковою редакцією доктора економічних наук А.Г. Бабенка. Дніпропетровськ : УМСФ, 2016. 328 с. ISBN 978-966-328-108-7 С. 85. 
may include: mini-lectures, group discussions, brainstorming, roleplaying games, discussions, participant presentations, consideration (analysis) of situations, etc. ${ }^{17}$

\subsection{Motivational and information-communication models of HR management in the process of adaptation}

The next tool we will highlight is Motivational Management as a type of management. In this model, priority is given to the motivation for business conduct, the relationship of administration and firm control, that is, the emphasis is placed on creating the conditions of interest in the end results. Motivational management is the construction of a management system based on the priorities of motivation and the choice of an effective motivational model. As you know, management science has developed various motivational models that have found wide practical application in successful firms in developed countries. Among them, the most traditional are:

- rational motivational model, which is based on the use of material incentives, ie rewarding or recovering from the results of work; motivational model of self-realization, the essence of which is to activate the person's internal motives, opportunities for self-expression, creativity in work, recognition of merit, expansion of independence and responsibility, career prospects and professional growth;

- motivational model of involvement (complicity) through the development of cooperation, partnership, participation in management, ownership, delegation of authority. Management through motivation is based on the study of the needs, interests, moods, personal goals of employees, as well as the ability to combine motivation with the production requirements and goals of the company. In such a model, personnel policy is oriented towards the development of human resources, strengthening the moral and psychological climate, implementation of social programs ${ }^{18}$.

17 Ibid

Реформування державної кадрової політики в Україні : навчальнометодичний посібник. Нац. акад. держ. упр. при Президентові України ; Нац. агентство України $з$ питань держ. служби ; Центр адапт. держ. служби до стандартів Європ. Союзу / ред. колегія : Ю.В. Ковбасюк (голова), К.О. Ващенко, Ю.П. Сурмін та ін. Київ : НАДУ, 2015. 408 с.

18 Підвищення ефективності використання персоналу та його розвиток : монографія / за науковою редакцією доктора економічних наук А.Г. Бабенка. Дніпропетровськ : УМСФ, 2016. 328 с. ISBN 978-966-328-108-7 C. 85. 
Labor motivation in the civil service should be represented by a complex system of motivating factors, including: material interest; selfrealization; job (job) promotion, which under current law must be ensured in the light of professional competence and honest performance of their duties; improvement of working conditions; others moral incentives, etc. Obviously, the desire to combine the needs of the public authority with the professional or personal interests and competencies of civil servants will contribute to higher productivity and increased interest in career development.

Information and communication tool for the development of civil servants that closely determines the quality of human resources through information and communication interaction (transfer of information from a source (communicator) to a recipient (recipient) by a certain channel) in the sphere of public service which implies the presence.

In this context L. Litvinov states: "Integration of knowledge into the circle of information space and communicative awareness is a necessary condition for the professional activity of civil servants, which responds to the challenges of today" ${ }^{\prime 1}$. That is, the ability of civil service employees to adapt to the modern information space and thus to carry out professionally communicative activities today helps to improve the style, forms and methods of work of the civil service, which increases the demand for education of a new generation of civil servants as highly qualified personnel.

\section{Experience of the State Migration Service of Ukraine (LCA) in the issues of adaptation of newly appointed civil servants}

In the State Migration Service of Ukraine, with the purpose of smoother entry into the staff and adaptation of the newly appointed employee in the workplace, the HRM developed and issued a "Beginner's Guide" during the appointment. This guide has 19 sections:

1) Check-sheet (instructions on what to do to the employee on the first working day, week, month, what are the actions of the employee at the end of the probationary period);

2) Our history;

3) Our mission and values;

${ }^{19}$ Ibid

Литвинова Л.В. Соціально-психологічний вимір побудови комунікацій державних службовців 3 громадськістю. Державне управління: теорія та практика. 2013. № 1. URL: http://nbuv.gov.ua/UJRN/Dutp_2013_1_24. 
4) The main tasks of SMS;

5) Structure of the SMS apparatus;

6) Management of the SMS;

7) Our contacts;

8) Why are you here?;

9) Your first day at SMS;

10) Schedule of work of SMS;

11) You are part of a large team;

12) SMS information systems;

13) Communication means;

14) Professional development and development;

15) Responsibility;

16) Rules of conduct in case of fire;

17) Rules on electrical safety (labor protection);

18) Communication standard;

19) Rules for internal service of the SMS.

This guide is part of the Adaptation Program and, in turn, serves as an auxiliary tool for adapting a newly appointed civil servant to the staff of the State Migration Service.

\subsection{Why is the process of adaptation of newly appointed civil servants in the SMS important?}

Each organization has its own culture, philosophy of functioning, expectations. Adaptation involves introducing the employee to the organization and introducing it to the tasks performed in the specific position. The adaptation process has four main goals:

-facilitating the initial stages of work when everything seems alien, unknown and complex to the employee;

- relatively quick formation of a newly-appointed friendly attitude to the organization;

- getting effective results of the new employee in the shortest possible time;

- minimizing the risk of an employee leaving the organization quickly.

Thanks to a well-organized adaptation process, employees who are properly recruited stay longer in the organization, have a clear vision of their role and place in the structure, and are quicker to contribute to the development of the institution. Giving the newly assigned person basic information that makes it easy to get started allows them to get used to 
the new situation quickly and with less stress to get involved in the life of the organization.

Adaptation gives the opportunity to familiarize the employee with the tasks, expectations and powers in this position, as well as the procedure for their implementation. It allows you to immerse yourself in organizational culture, values, get acquainted with strategy, mission, vision of the future, history of SMS and interpersonal relationships in informal groups. A new employee can gain autonomy, self-confidence, attain skill in action, and master the practical part of their organizational role. An effective adaptation process helps the employee to become proficient and in a short time become a full member of the team.

It should be emphasized that there is an interdependence between high staff turnover and quality of the process of adaptation of employees. Most of the redundancies in the first year of work at the organization stem from the fact that the newly recruited did not adapt to the organizational culture or that the employee's expectations of the job he or she had during the selection were not met.

\subsection{Tools and methods of adaptation of newly appointed civil servants in the SMS}

Adaptation involves conscious management of the process, organization of actions that reduce the risk of failure, and accelerate the process of adapting the employee to new working conditions.

During the process of employee adaptation, many organizations turn to proven tools to support them. In view of the appointment, such tools can be divided into: 1) welcoming and integration activities 2 ) informing about the organization, unit and position 3) informing about the role in the organization and development opportunities, and 4) preparing for the position (Table 2). 
Adaptation tools

\begin{tabular}{|c|c|}
\hline Action Category & Adaptation tools \\
\hline $\begin{array}{l}\text { Measures of } \\
\text { welcome-integration } \\
\text { character }\end{array}$ & $\begin{array}{l}\text { - a welcome letter or e-mail signed by the head of the } \\
\text { institution; } \\
\text { - presentation of the employee to other members of the } \\
\text { team; } \\
\text { - e-mail informing other members of the staff of the } \\
\text { appointment of a new employee (often with brief } \\
\text { biographical information about the newly-appointed } \\
\text { employee and the title of his/her position); } \\
\text { - integration meetings; } \\
\text { - appointment of a mentor (immediate supervisor or } \\
\text { person designated by him) }\end{array}$ \\
\hline $\begin{array}{l}\text { Organization and } \\
\text { workplace } \\
\text { information }\end{array}$ & $\begin{array}{l}\text { - brochures and guides in paper and electronic form, } \\
\text { containing information on the nature of the organization, } \\
\text { its history, mission, strategy, structure, etc., as well as the } \\
\text { procedures, regulations, etc. adopted; } \\
\text { - fire information on the Internet about the procedures } \\
\text { adopted in the organization, regulations, ethics, prevention } \\
\text { of corruption introductory training and adaptation training } \\
\text { courses; } \\
\text { - related to labor law, procedures that operate in the } \\
\text { organization }\end{array}$ \\
\hline $\begin{array}{l}\text { Informing about the } \\
\text { role in the } \\
\text { organization and } \\
\text { prospects of } \\
\text { development of the } \\
\text { person holding a } \\
\text { certain position }\end{array}$ & $\begin{array}{l}\text { - meetings and conversations with a supervisor about an } \\
\text { employee's career development materials; } \\
\text { - documents defining career development plans, basics of } \\
\text { career paths, promotion procedures, etc.; } \\
\text { - periodic assessment; } \\
\text { - creation of individual plans for professional } \\
\text { development }\end{array}$ \\
\hline $\begin{array}{l}\text { Preparatory work for } \\
\text { the position }\end{array}$ & $\begin{array}{l}\text { - meetings with the manager to determine the } \\
\text { responsibilities, tasks and responsibilities associated with it; } \\
\text { - trainings, which represent the correct order of } \\
\text { accomplishment of tasks; } \\
\text { - work under the guidance of (usually a mentor); } \\
\text { - external training courses related to the field of } \\
\text { completed tasks }\end{array}$ \\
\hline
\end{tabular}

Among the adaptation tools mentioned above, we should focus on those that are of particular importance in the adaptation process. These are, first of all, brochures and handbooks of a welcoming and informative nature, which operate in practice in both paper and electronic forms. Their purpose is to provide information in a simple and unambiguous way about the organization. This explanation is useful 238 
because it groups the information in one place that is accessible to the employee and relieves him or her of the burden of self-searching. The information usually contained in the following documents covers:

- history, culture, values adopted, traditions and other information useful in adapting to a new place of work;

-SMS strategy, its mission, vision for the future and goals set for it;

- organizational structure;

-internal procedures regarding, for example, communication, workflow, organization of working time;

- useful phone numbers and other contact information;

-working rules, such as dress code, organization language;

- plans of houses.

The advantage of brochures and reference books is that they can always be returned when the need arises. However, the organization should not rely solely on the printed word and procedures. The success of the adaptation process depends mainly on direct contact with the supervisor or mentor, as well as the feedback that follows.

Appropriate selection of a mentor significantly affects the success of the entire adaptation process. A mentor is a person who supports the employee, gives him a sense of security, and at the same time is responsible for the successful progress of the adaptation process. The mentor closely interacts with other actors responsible for the process, ie the immediate manager and HR specialist, as well as with other members of the newly appointed team.

It is the duty of the mentor to provide advice and assistance to the employee in the course of work, to facilitate contact with relevant persons in the organization and to intervene in difficult situations.

Often, this responsible role is assigned to the directors or experienced employees of the organization, who have well-developed social competencies, professionalism, authority and, as a rule, many years of experience. Selection of a talented mentor is a key element in the adaptation process. It is not necessary, however, to be discouraged by the lack of a flawless person in an organization that can be trusted with a new employee in care. One of the main ideas of this process is the simple help offered to new employees. The job of the mentor is to skillfully introduce the newcomer to the organization and build his/her skills through training and transfer of experience.

Training is also needed. In particular, an introductory training course, which is attended by all employees, who start working in the organization. It is most often concerned with labor law, occupational 
safety and health issues, as well as fire safety rules. The second group of courses are those that introduce and have an individualized character and depend on the type of position, its place in the organizational structure, as well as the employee's awareness of the problems of work in the position. It is important for employees to clearly define the responsibilities, scope, tasks, expectations and responsibilities that are associated with it. Accordingly, the instructions given have a huge impact on the quality of the tasks in the new position and the effectiveness of the goals of the organization and the newly appointed.

\subsection{Duration of adaptation of the newly appointed civil servant and ways of achieving the goals during the holding}

The adaptation process starts already during the interview at the selection stage, in particular the last part of the selection. The person conducting the meeting often briefly tells the candidate about the organizational structure, job responsibilities or internal and external communication.

There is no clear answer to the question of how long the process of employee adaptation takes. It can take 1,3 or 6 months. Most importantly, it should end with the full introduction of a new employee to the position and his independence.

In a well-conducted adaptation process, it is essential that it does not occur too quickly. These are situations where a new employee is "bombarded" with a wealth of information in the early days and is taught to use sophisticated tools. Instead of feeling cared for, the newly appointed feels more depressed and disoriented.

The most important benefits of an employee adaptation process in an organization are, above all:

-higher motivation and activity of new employees;

- greater self-identification with the organization and better team relationships;

- faster adaptation of the employee, which affects his efficiency and independence;

- a better atmosphere at work;

- better feedback on your employer (such as Facebook, online forums, etc.);

- fewer exemptions after the end of the probationary period;

-less turnover. 


\subsection{Finishing the adaptation process for a newly hired employee}

How to make the process of adapting employees in the organization the right way, based on modern solutions? First of all, you need to monitor this process. To do this, use the following list of questions:

1) Do newcomers feel properly accepted for their new job?

It is necessary to analyze the first working days that are going through the newly appointed. To do this, one or two working months should be asked about employees' feelings about entering a position, such as how they felt the first week. It should also be asked which of the employer's actions influenced the newly recruited to feel properly accepted and what, in their view, could lead to more effective recruitment.

2) Is the newly recruited employees a holistic view of the organization?

New employees need to know and understand the vision of the future, the mission and, above all, the goals of the organization. It is important for them to be aware that they are working for a unique employer. In order to achieve this, an emphasis is placed on organizational culture and the values that drive the organization during the adaptation training course.

3 ) Is the employee recruitment program interesting?

The tedious adaptation process has a bad effect on building a new employee's activity. Moreover, it gives the newly-appointed signal that he or she is in an unprofessional environment, which in turn leads to less respect for the employer. A well-organized adaptation should include elements both formal (brochures, informational materials), and practical (adaptation training courses, meetings with the head, mentor, team).

4) Do new employees have problems getting the information they need?

An important part of bringing in a new employee is to have broad access to the information he or she needs at the moment, as well as the ability to ask questions. If an organization has an intranet (internal network) where information about the organization is accumulated, it creates an opportunity for a new employee to search for all the information he or she currently needs. Also being able to ask questions of management and senior colleagues freely reduces stress and anxiety. If these two factors (the knowledge base of the organization and the friendly attitude to the newly recruited) are realized, the employee being hired will not waste valuable time and energy searching for the necessary information. 
5) Does the organization have an effective tutorship program? Tutorship is a very effective tool in the recruitment process. The newly recruited employee receives a person to assist him/her in the initial period of work to cope with the difficulties. The individuals who are assigned mentors to new employees also gain a great deal: reputation, recognition, and opportunities to develop in a variety of areas, such as employee supervision or leadership. The benefit of this for the organization itself is, first and foremost, a reduction in the time it takes for a new employee to be effective.

6) How does an employer demonstrate that a new employee is important to him/her? From the outset, you need to involve employees in the work. They need to be assigned tasks that cause a sense of satisfaction. This is extremely important now that candidates from the millennial generation are coming to work who need to be aware that they are making a direct contribution to the development of the organization. Therefore, in the course of employee adaptation, it is recommended to focus on individual development and provide a sense of real impact on the results achieved by the organization.

7) Is the role of the manager in the adaptation of the employee sufficiently active?

One of the most important in terms of a new employee is the factor that influences the correct and effective implementation of the organization is the position of the manager. He must receive training on the appropriate handling of the new employee. In order to make the first weeks of work for a newly recruited person an interesting and effective experience, the supervisor must give him or her the opportunity to ask questions and also provide him/her with current feedback. It should also establish the scope of the tasks and responsibilities and communicate its expectations regarding the order in which they will be implemented.

The application of the above solutions in the process of adapting new employees should bring numerous benefits to the employer. First of all, they can create an atmosphere that will increase the activity of employees (new and already employed) and increase their efficiency.

\section{CONCLUSIONS}

So, to summarize the above, we can state that the formation and development of personnel capacity of the civil service is an important function of the work of any state institution, organization, enterprise. Effective functioning of public authorities depends to a large extent on the timely and complete solution of socio-economic and organizational problems. 
However, providing public administration to highly qualified professionals is a complex, continuous process that increases the efficiency of the entire civil service system. According to historical practice, the formation of a state personnel policy can be effective if certain requirements and conditions are met, and it involves the consistent implementation of a number of research, organizational, administrative, political and legislative actions.

Adaptation is a complex, multidimensional process, the success of which depends on both the employee and the actions taken by the organization. In practice, some organizations leave a new employee without support in the form of adaptation measures, believing that sooner or later he or she will adapt to the organization on its own. The employee acquires knowledge about the work environment - information about the work itself, as well as the norms, values and traditions adopted by the organization. This can sometimes result in the employee having a distorted picture of organizational realities due to the fact that he or she encounters random, fragmentary or false information.

Conscious management of the adaptation process by the management of the organization consists in the implementation of planned actions aimed at reducing the risk that the employee will not be adapted. This strategy has many benefits, for example: a lower risk of firing a newlyhired employee, a greater sense of security that strengthens his or her relationship with the employer and increases activity in the workplace, faster learning of a new professional role, and shorter duration of the adaptation process. This approach requires the development of an employee adaptation program and then a consistent implementation. Managing this process is especially effective when it leads to the coordinated action of all the entities involved in the process.

It is also important to emphasize the fact that the new wording of the Law of Ukraine "On Civil Service" establishes a competent approach to human resources management in public administration. This approach is based on taking into account the knowledge, skills and abilities of the staff, as well as their personal qualities, which enable, through the implementation of the adaptation process, to realize their professional potential in practice.

Taking into account the above definitions, in our view, it becomes clear that adaptation should be considered through the prism of forming the capacity for creative and innovative activity of employees, which can be further used to fulfill and achieve the strategic functions of the public authority. In fact, this means that adaptation enhances the activity of a newly appointed public servant of a public authority. 


\section{SUMMARY}

This paper examines the nature of the adaptation process for newly appointed civil servants. It is established that in order to speed up the process of entry of a recruited employee into the position and increase the efficiency of activity in a short time; minimizing losses and errors in the process of adaptation and assimilation of duties by an employee; reduction of staff turnover. In order to develop a positive attitude towards professional activity and the relevant public authority, it is necessary to develop adaptation programs in which it is important to take into account factors that relate to the specifics of the organization, on the one hand, and the categories of new employees to whom the program is focused - on the other.

The following adaptation management entities are identified: organization manager, HR professionals, line managers, mentors, and the following adaptation methods are described, such as: coaching (explaining and demonstrating the basics, rules, and practices directly in the workplace); courses (eg refresher courses), trainings, seminars; discipleship and mentoring (tutorship, tutoring, coaching); shading or pocket-sweeping; badding; business games and more.

Comparative analysis of non-formal vocational training tools in the field of civil service was conducted in the context of four tools such as tutorship, mentoring, tutoring, coaching for this purpose, context; number of wards; value from: the mentor's experience and professionalism, experience, knowledge of the mentor and his/her willingness to share this knowledge, individual training, coaching skills and motivation (in the context of each tool under consideration); content; goal; progress; level of responsibility; method; intention.

In the context of adaptation the motivational model of personnel management in the process of adaptation is considered. The essence of this model lies in the priority of motivation for business conduct, relations over administration and firm control, that is, the emphasis is placed on creating the conditions of interest in the end results.

There is also an example of the adaptation of the newly appointed employees to the posts of the State Service of the State Migration Service of Ukraine (SMS). The tools through which the process of adapting newly appointed civil servants to the SMS are given.

\section{REFERENCES}

1. Про державну службу : Закон України від 10 грудня 2015 року № 889-VIII. Відомості Верховної Ради Украӥни офіційне видання від 22.01.2016, 2016 р., № 4, стор. 60, стаття 43. 
2. Перерва А. Адаптація як пристосування працівника до умов праці в державному органі. Журнал "Держслужбовець», липень 2018, № 7.

3. Маслова В.М Управление персоналом : учебник и практикум для академического бакалаврита 2-е изд., перераб. и доп. Москва : Издательство Юрайт, 2015. 492 с. Серия : Бакалавр. Академический курс.

4. Селіванов С.В., Обушна Н.I., Хаджирадєва С.К. Розвиток кадрового потенціалу державної служби в Україні в умовах реформ : проблеми теорії та практики : монографія. Київ : Вид-во «Каравела», 2019. 292 с.

5. Рашитова Н.К. Адаптація до професійної діяльності на державній службі: соціально-психологічний аспект : автореф. дис.... к.е.н. : спец. 25.00 .03 «Державна служба». Дніпропетровський регіональний інститут державного управління. Дніпропетровськ, 2007. С. 15.

6. Нижник Н.Р. Проблеми сьогодення державного управління в Україні. Університетські наукові записки. 2007. № 3 (23). С. 14-19.

7. Tillman L.C. Mentoring new teachers: Implications for leadership practice in an urban school. Educational Administration Quarterly. 2005. No. 41(4). Pp. 609-629.

8. Coaching and mentoring - the difference. Brefi Group. URL: http://www.brefigroup.co.uk/ coaching/coaching_and_mentoring.html.

9. Поліщук І.В. Механізми забезпечення розвитку професійного потенціалу державних службовців в Україні : дис. ... канд. наук 3 державного управління. Київ, 2018. 315 с. С. 177-178.

10. What's the difference between coaching, mentoring, counselling and training? Culture Shock Coaching. 13.10.2010. URL: ttps://cultureshockcoaching.wordpress.com/2010/10/13/hello-world/.

11. Random House Kernerman Webster's College Dictionary. 2010. $\mathrm{K}$ Dictionaries Ltd. by Random House, Inc. URL: http://www.kdictionaries-online.com.

12.Parsloe E. The manager as coach and mentor. London : Institute of personnel and development, 1999. $89 \mathrm{p}$.

13.Пархоменко-Куцевіл О.I. Теоретико-концептуальні засади удосконалення механізму адаптації кадрів державної служби. Державне управління: теорія та практика 2010. № 1. URL: https://scholar.google.com.ua/citations?user=2dzHkEsAAAAJ\&hl=ru.

14. Kenworthy J. Leadership Coaching: What's Better Today? How to Grow and Learn into the Leader You Can Be. Corporate Edge Asia Pte Ltd, 2013. 163 p. 
15. Підвищення ефективності використання персоналу та його розвиток : монографія / за науковою редакцією доктора економічних наук А.Г. Бабенка. Дніпропетровськ : УМСФ, 2016. 328 c. ISBN 978-966-328-108-7 С. 85.

16. Реформування державної кадрової політики в Україні : навчально-методичний посібник. Нац. акад. держ. упр. при Президентові України ; Нац. агентство України 3 питань держ. служби ; Центр адапт. держ. служби до стандартів Європ. Союзу / ред. колегія: Ю.В. Ковбасюк (голова), К.О. Ващенко, Ю.П. Сурмін та ін. Київ : НАДУ, 2015. 408 с.

17. Литвинова Л.В. Соціально-психологічний вимір побудови комунікацій державних службовців 3 громадськістю. Державне управління: теорія та практика. 2013. № 1. URL: http://nbuv.gov.ua/UJRN/Dutp_2013_1_24.

\section{Information about authors: Selivanov S. V.,} Candidate of Science in Public Administration (Ph.D), Head of Human Resources Department State Migration Service of Ukraine 9, Volodymyrska Str., Kyiv, 01001, Ukraine

Kashlakova A. I., Head of Sector "Training and Methodological Center" of the Human Resource Department State Migration Service of Ukraine 9, Volodymyrska Str., Kyiv, 01001, Ukraine 